\title{
Man-Woman Relationship in Shobhaa De's Second Thoughts
}

Dony Preethii. J.J

Research Scholar (Full-Time)

Virudhunagar Hindu Nadars' Senthikumara Nadar College (Autonomous)

Virudhunagar, Tamil Nadu, India

donypreethiijeyaraj96@gmail.com

Dr. M. Meena Devi

Associate Professor of English

Research Centre in English

Virudhunagar Hindu Nadars' Senthikumara Nadar College (Autonomous)

Virudhunagar, Tamil Nadu, India

kameeradevi@gmail.com

DOI: https://doi.org/10.24113/ijellh.v9i4.10993

\begin{abstract}
Shobhaa De's Second Thoughts is a realistic representation of the psyche of the traditional Indian men and women. The freedom of women is permitted in a very restricted manner in the Indian Society. This novel is the ancient story of sacrifice and adjustment that a woman is destined to. Maya, the protagonist, lives in loneliness and sadness. In Second thoughts, Maya learns to survive in the sultriness of not only Bombay, but also of her marriage life. She strikes up a friendship with Nikhil, her charming, college-going neighbor leading to love and betrayal. The
\end{abstract}


way Shobhaa De narrates each and every aspect of human relationship in general and manwoman relationship in particular, is really wonderful. This paper aims to explain the emotional and psychological needs of Maya and also gives the picture of the modern urban woman who is subjugated and suppressed in the meaningless marriage.

Keywords: Marriage, Subjugation, Suppression, Marginalization, Loneliness.

The status of woman depends largely on the simple biological fact that she is inferior to man and that is why she is usually restricted to her traditionally assigned roles. Since time immemorial, a woman has been the victim of male domination and oppression and is treated like a beast and an object for pleasure. Man has always looked down upon her as the weaker sex and his sole property. Besides, many religions of the world have given sanction to the female's subjugation to the male members of the society. As a matter of fact, a woman is born to be as free as man but she is victimized and subdued by the male community everywhere in patriarchal culture. She has been the subordinate sex, the second sex and has to conform to male standards. The term 'man' usually denotes the entire human race whereas woman is silent and not mentioned.

Shobhaa De, a modern novelist, famous for portraying the straight forward issues of the women in the contemporary society. She believes that sex, is the root of energy. Her novel analyses the aspects of sex, which is a great urge. Her novels starts with the letter ' $\mathrm{S}$ '. De is gifted with an extra - ordinary ability to discuss the most sensitive topic of human life. She narrates the man-woman relationship, is really a wonderful one. Many people criticize her for the open discussion of the sexual matters. But her novel has got a tremendous response from people all over the world. Second Thoughts is her seventh novel, is a bitter love story. 
Second Thoughts represents the psyche of the traditional Indian men who still cherish and nourish the age old norms and traditions. In that much familiar pattern, the status of Indian men and women has hardly undergone any change. As individuals, they may have progressed but in the institution of marriage, the man is still the lord and a woman has to abide by his whims and fancies whether she likes it or not. The middle class family of a girl is ready to bow down to whatever whims and demands the boy's family makes.

Shobhaa De is familiar with the life-styles of the so-called elite societies of the metropolitan cities of India. Her keen observation and deep insight into human-relationships has enabled her to handle man-woman relationships deftly. De believes that Indian women are prepared for their modern roles, while men are trapped by history. Among the various issues pertaining to the problems of married life, extra-marital affair plays a vital role. Extra marital affair takes place when one of the life partners cheats their spouse by having an affair with another person. It is applicable to men as well as women, because it is very common between both the sexes. Mostly it happens because of unfulfilment of marital sexual life and lack of understanding and love between the couples.

Second Thoughts deals with a young middle-class Bengali girl, born in Calcutta. Maya, an educated and freedom loving girl, who enters into arranged marriage with a foreign returned Bengali boy Ranjan, a bank executive. The reason for liking Ranjan is her desire to be a part of the Mumbai world which to her is like a dreamland of glamour and beauty. Maya is more interested in Mumbai than Ranjan. "Marrying Ranjan would make her a part of it immediately. If she were lucky enough to become the other Mrs. Malik, Maya knew she'd be bonded with Bombay forever"(13). Ranjan is very conservative on the question of Maya's career in textile designing he declares, "I am earning well enough to support a wife and family. I believe it is a 
woman's duty to run a good home" (11). In any Indian family, the husband's comforts always come first. Everything else follows. A woman has to sacrifice al her dreams. Later, on their way home Maya says: "How could they tell me not to work after marriage? Do any educated, trained girls stay at home these days; I didn't like that remark" (18).

Maya's disillusionment begins after marriage when she lands in Bombay. She realizes that despite Ranjan's stay abroad, he is very traditional and above all, an insensitive husband. He imposes restrictions on her. The agony of Maya, who feels trapped in matrimony, is the central theme of the novel. Maya is eager to catch the life-style of Mumbai but her husband turns out to be a cold Indian male who believes that by marrying the girl he had bestowed a favour upon her. Ranjan tries to be an opposite of Maya and hates whatever is liked by her - even flowers or simple outings. Maya wants to be a perfect wife but she finds situations uneasy as he always wants all her attention towards himself. His attitude is self - centered. She says to Ranjan: "The truth, dear Mr. Malik, is that you have me here as a fulltime, domestic servant without pay. Shall I tell your colleagues that? And also tell them that you have forbidden me from pursuing a career even a part time one". (217)

Maya is not allowed to use phone at home, she is like a caged bird. De captures the middle class psyche by exposing various facets of Ranjan- his attitude to hold on tight to the purse strings so as to control his woman, his lectures on wifely duties, and his complete control even on the use of the air conditioner. Maya knows that Ranjan can dare to do such things because he feels superior in some way to her and her background. Ranjan's relationship with his mother is clear. He adores her and always gives examples of his mother to Maya and asks her to learn from his mother. He is a true son but not a husband. He does not share anything with Maya while he always gives his all report of the day to his mother. Due to his mother's over- 
indulgence in their personal married life Ranjan is not able to relate with Maya. Ranjan's mother wisely makes selection of Maya as her daughter-in-law for her wants that a wife should act under the thumb of the husband. She says:

It is always wiser to get a girl from a socially inferior background. ... A wealthier wife spells doom. The husband loses all control over her and she ends up having the upper hand. Such a marriage can never work which is why we were so careful while selecting the right candidate for Ranjan.

Maya's longing for adventure and romance often suffers a setback. Ranjan's responsibility towards Maya is nothing beyond providing her financial support, a house and four square meals a day. His complete indifference to Maya's emotional desires hurts Maya immensely. He even refuses to share a single aspect of his life with her. So Maya feels miserable in his company. Although she is not tortured physically or in other way but she feels as she is losing her identity in his company. She says: "With him around, I seemed to hold my breath and walk around on tiptoes trying to appear as invisible as I possibly could" (129). Maya once asks him to take her out at least during the weekend. Ranjan replies: "Sometimes you talk like such a kid. Life isn't picnic, you know. And you are not in Bombay on a holiday. As a married woman, you have to learn to deal with responsibilities" (29).

Duty not only means to provide food, home and money, it also includes a certain amount of respect and affection for one's spouse. Under the same roof, they live as strangers as their sexual relationship is not normal. There is no lovable relationship between husband and wife. When Ranjan returns from Calcutta, Maya cares him but in horror Ranjan jumps back and scolds her: "Stop behaving like a cheap woman. A prostitute, he had muttered before turning around 
and going to sleep"(284). Maya cannot share her feelings with anyone; she cannot bear any child because of her husband's lack of interest in physical - gratification and she has nothing creative to do in that city. She is in the miserable condition. In reality she is neglecting by her husband, in-laws and even by her own parents. She feels:"Nobody needed me, absolutely nobody. My parents no longer thought I belonged to them. My husband belonged to his mother. It was unlikely that I would bear children who would belong to me. And I did not have a single true friend to call my own”. (292)

The hollowness of such marriages is evident even in the case of Maya's parents, who hardly ever talk to each other and even their quarrels or heated arguments were out of question. Maya's own case is far more pitiable: "Now here we were, locked together in a relationship that didn't satisfy either of us" (352). When Maya meets Nikhil, her college going neighbour who is cool and friendly, she feels that she has her own identity. Nikhil makes Maya feels that she has right to exist. She enjoys his company. But her consciousness makes her feel ashamed. Her loyalty to Ranjan holds her back on a couple of occasion. Through Maya, De shows the attitude of middle class urban women. She takes the side of her husband. She thinks that Ranjan is not bad. Although Maya is loyal to Ranjan but she also wants to remain in Nikhil's company as he brings a new meaning of existence for her.

De wants to show that now woman has learnt to establish her identity. She can take any decision fearlessly and boldly. Maya does not want to cheat her husband but only to enjoy her life in the open air with her own emotions and feelings. Nikhil enlivens her spirit and seems to understand her better than her husband, thus giving Maya a feeling of comfort which she had desperately looked for because her yearning for Ranjan's love could not find the fulfillment she needed. 
Nikhil is the fourth floor neighbour's son and junior to Maya by six years. When Maya is with Nikhil she does not think of anything. She wants to express her joy and happiness. When once Ranjan goes out of his business tour for ten days, Maya feels free as a bird and allows her spirits to soar. She says: "His exit always generated a sense of exhilaration not because I did not want him around. But I felt free to breathe normally" (129). At this time Nikhil comes to Maya and asks her to go with him on riding. She agrees and enjoys a lot there. She says: "For the first time since my arrival in your city, I felt like laughing, singing, enjoying the salty sea are on my face. I looked at the sky and felt happy" (270).

Maya's friendship with Nikhil goes to the extent of physical intimacy. Their sexual union heals the wounds of Maya's loveless marriage. A distressed woman is thus liable to seek out comfort from some other source. Maya is in a deep sense of guilt. But she tries to overcome this guilt and resolves to live in the present. The initial guilt of allowing Nikhil to visit her later gives way and makes her confident to deal with either Ranjan or her mother-in-law if they happen to arrive. She thinks she should have made adjustments and compromises because marriages need a great deal of effort to run smoothly. Maya would recall her mother's words: "The issue is, Maya, marriage involves sacrifices. And all the sacrificing has to be undertaken by the woman. The sooner you accept that, the happier you will be" (353).

With a little encouragement from Nikhil, now Maya is prepared to say goodbye to her present life with Ranjan without the slight regret. But the news of Nikhil's engagement with another girl left Maya shocked and stunned. When Maya wants to take bold decision, once again she is left all alone with her unsympathetic husband and mother-in-law. Maya has the glimpse of a modern woman inside her. She has courage to take bold step, but the circumstances do not help 
her in her decision. Nikhil seduced Maya and doesn't come forward to marry her. It is at this juncture that Shobhaa De throws light on the reality of the people who fall in Nikhil's category. He takes advantage of the limitations and weakness of lonely ladies and Maya is just an addition to his endless list. De wants to show what woman has to pay for marriage is often too high. Circumstances compel Maya to change her mind and in desperation she deceives Ranjan, otherwise she is not a woman of easy virtue. But ironically, the novel ends by Maya deceived herself.

De's women have crossed the barrier of two thousand years old suppression and are on the verge of retaining their lost glory. In De's novels this standard equation has often been radically altered and women with increased awareness of gender roles and gender identity have emerged as serious contenders of power game. They participate actively in this game of power to manipulate, deconstruct and to create new traditions. De rightly observes:

Eventually every relationship is a power struggle either on an overt or subliminal level. Control over the situation has been a male prerogative over the centuries. Women's destinies have been determined largely in that context alone. It is time they were made aware of their potential and power. Man will have to come to terms with woman power. (112-13)

Shobhaa De's fiction does not reclaim the lost treasures of tradition but to move ahead with the changed moods of society. In this respect, De as a feminist writer often presents an account of her own life's experience, which enables her readers to be aware of the change in reality. No longer is woman a scrubbing maid and a docile bed-partner. She manipulates to live 
lavishly by controlling her husband's sexual urges. The image of man that emerges from De's novels is generally negative. A male character is almost invariably portrayed as seducer, exploiter, wife-beater, rapist, torturer, or a cruel and callous husband or a weak character. Her women characters act according to the dictates to their own will and defy the farcical codes the social system. It seldom records a woman's story in its entirety. De deconstructs the tradition and explores the experiences of women nearly on all her novels. De boldly rejects all kinds of subterfuge and communicates the unprintable aspects of woman's story. 


\section{Works Cited}

De, Shobhaa.Second Thoughts. New Delhi: Penguin Books Ltd, 2013.Print.

De, Shobhaa.Shooting from the Hip. New Delhi: Penguin, 1992. Print. 